$\mathrm{UH}$

iti

Universität Hamburg
Faculty Economics

and Social Sciences

Chair for Economic Policy

A. FEDDERSEN / W. MAENNIG

SECTORAL LABOUR MARKET EFFECTS OF

THE 2006 FIFA WORLD CUP

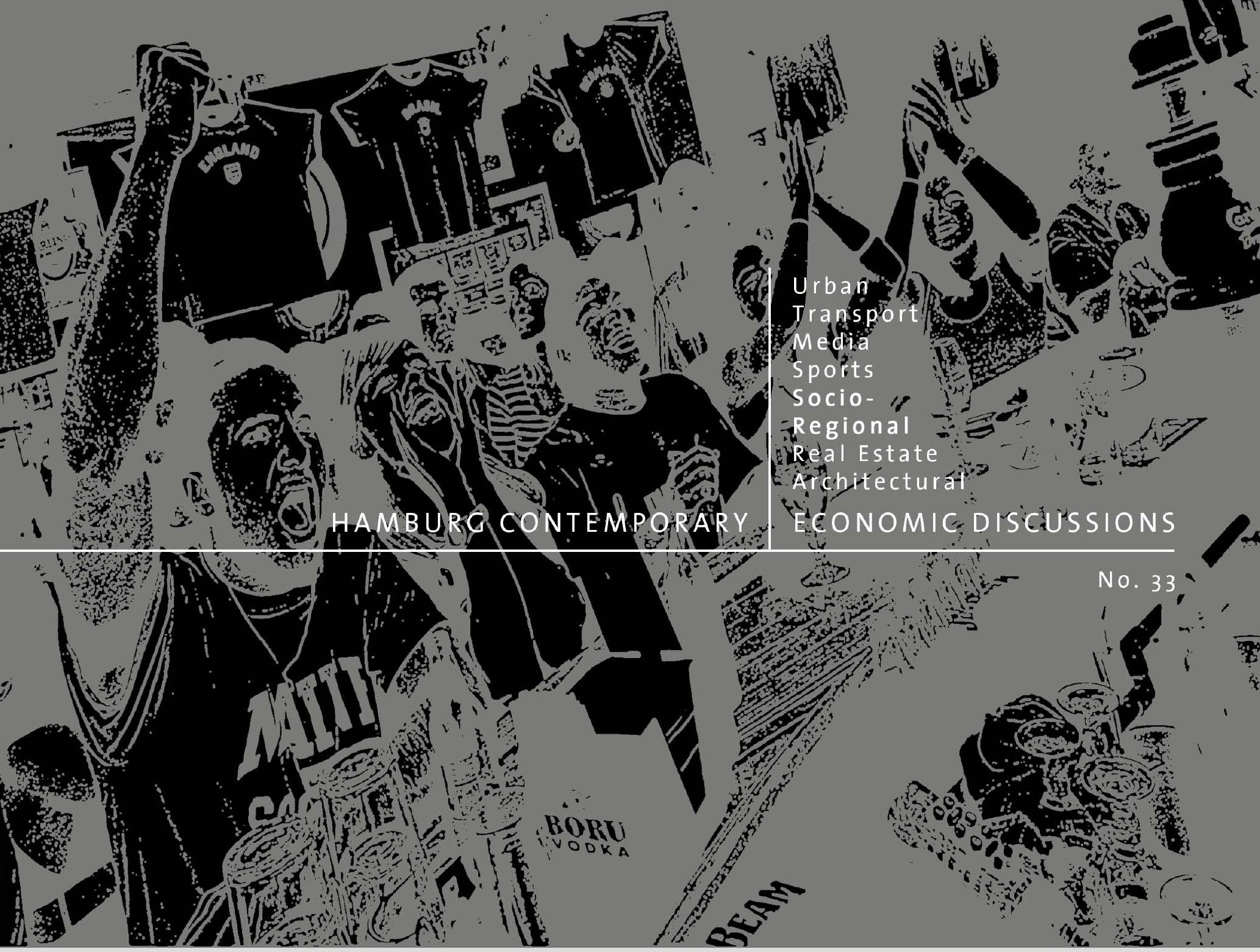


Hamburg Contemporary Economic Discussions University of Hamburg Faculty Economics and Social Science Chair for Economic Policy Von-Melle-Park 5 D-20146 Hamburg | Germany Tel $+494042838-4622$ $\mathrm{Fax}+494042838-6251$ http://www.uni-hamburg.de/economicpolicy/

Editor: Wolfgang Maennig

Arne Feddersen

University of Hamburg Faculty Economics and Social Science Chair for Economic Policy Von-Melle-Park 5 D-20146 Hamburg | Germany Tel +49 $4042838-4628$ Fax $+494042838-6251$ feddersen@econ.uni-hamburg.de

Wolfgang Maennig University of Hamburg Faculty Economics and Social Science Chair for Economic Policy Von-Melle-Park 5 D-20146 Hamburg | Germany Tel +494042838 - 4622 $\mathrm{Fax}+494042838-6251$ maennig@econ.uni-hamburg.de

ISSN 1865 - 2441 (Print) ISSN 1865 - 7133 (Online)

ISBN 978 - 3 - 940369 - 80 - 2 (Print) ISBN 978 - 3 - 940369 - 81 - 9 (Online) 


\title{
Sectoral Labour Market Effects of the 2006 FIFA World Cup
}

\begin{abstract}
Using the case of the 2006 FIFA World Cup, this study is the first to test the employment effects of a mega-sporting event on the basis of data that are both regional and sectoral. It is also the first study of sporting events to use a non-parametric test method. Earlier studies on the World Cup could not identify any employment effects. In contrast, we find a small but significant positive employment effect on the hospitality sector and a negative effect on the construction sector. To our knowledge, this is the first time that such a crowding-out effect of public investment on the occasion of a mega-sporting event has been found in an empirical analysis.

Keywords: FIFA, World Cup, Economic Impact, Ex-post Analysis, Sectoral Employment

JEL classification: H54; R12; L83
\end{abstract}

Version: February 2010

\section{Introduction}

"And the winner is ... Deutschland!" On June $6^{\text {th }}, 2000$, these were the words of FIFA President Joseph Blatter as he announced the host of the 2006 FIFA World Cup. The related investment costs for new construction or major renovations totalled nearly $€ 1.6$ billion for the twelve stadiums (FIFA, 2006). An additional $€ 1.6$ billion was invested in stadium-related infrastructure in the host cities. In some other cities that had unsuccessfully participated in a national competition, each hoping to become a World Cup host city, another $€ 515$ million had been spent on stadium construction.

Before the 2006 World Cup in Germany, a series of analyses was published indicating that the investments related to staging the World Cup and the expenditures of the expected one to two million foreign visitors would markedly affect income and employment. The estimates fluctuated, indicating a $€ 2$ billion to $€ 10$ billion increase in income or up to 10,000 additional jobs (see e.g., DEUTSCHE INDUSTRIE- UND HANDELSKAMMER, 2006; DEUTSCHE POSTBANK AG, 2005a, 2005b, 2006). 
The evidence from the few existing ex-post studies of the 2006 FIFA World Cup is less optimistic. Using poll data, KURSCHEIDT, PREUß, \& SCHÜTTE (2008) calculated World Cup-induced (substitution-adjusted) consumer spending of $€ 3.2$ billion. This seems to be an impressive figure at first glance, but if one compares it to Germany's GDP in 2006, which totalled $€ 2,325$ billion, then there was only a small income impact of $0.14 \%$. Thus, it is not surprising that scholarly researchers using aggregated macroeconomic time series hardly succeeded in identifying any significant economic impact from the event. BRENKE \& WAGNER (2007) and MAENNIG (2007) found no significant impact of the World Cup on economic indicators (e.g., GDP) at the country level. On such an aggregated level, any positive impact of a mega-event would almost certainly be subsumed by normal fluctuations in the economy and would, from a statistical point of view, disappear into the noise. There are three studies that used more disaggregated data. HAGN \& MAENNIG (2009) analysed monthly unemployment data for the 75 largest urban districts ("kreisfreie Städte") in Germany, including the 12 World Cup venues. Their focus is on the effects of staging the event. FEDDERSEN, GRÖTZINGER, \& MAENNIG (2009) examined whether the investment in stadiums and related infrastructure led to greater economic development in the host cities. Neither study demonstrated any significant impact on regional economies. ALLMERS \& MAENNIG (2009), however, did identify some 700,000 additional overnight stays by non-residents and $€ 570$ million in net national tourism income.

The general failure to identify tangible mesoeconomic or macroeconomic effects does not mean that such events have no economic benefit. Potential intangible effects like a "feel-good" effect and/or an improvement in the international reputation of a country (ALLMERS \& MAENNIG, 2009) must be acknowledged.

This paper takes up the argument that the impact of even a mega-event like the FIFA World Cup, organised in a large economy, is too small to be measured with aggregated data as was done previously. We consider reports from media companies indicating that there were considerable increases in viewer ratings for the World Cup (N.N. 2007a) and reports of increased turnover for manufacturers of table-football equipment and for breweries. We use such reports to establish the 
economic hypothesis that any economic impact of a mega-sporting event might be spatially and temporally localised and, thus, that more disaggregated data must be analysed. The aim of this paper is to test economic impact on the basis of regionally and sectorally differentiated employment figures.

The remainder of the paper is organised as follows: Section 2 gives a brief literature review, while Section 3 describes the data and the empirical strategy. Section 4 presents the econometric results and, finally, Section 5 presents the conclusions.

\section{Literature Review}

Since the studies by BAADE (1987) and BAADE \& DYE (1988, 1990), a growing body of literature on the economic impact of professional sports franchises, facilities, and mega-events on the (local) economy has developed. The results presented in this literature are strikingly consistent (COATES \& HUMPHREYS, 2008). No matter which geographical units (e.g., cities, counties, Metropolitan Statistical Areas, states) are examined, no matter which model specifications, estimation methods and dependent variables (e.g., employment, wages, taxable sales) are used, and no matter which part of the world is under study (e.g., the USA, Europe) scholarly analyses provide almost no evidence that professional franchises, sports facilities, or mega-events have a measurable impact on the economy (COATES \& HUMPHREYS, 2008, p. 302).

To our knowledge, very few studies have found significant positive effects from sports facilities and sports events ex post. BAIM (1994) found positive employment effects from MLB and NFL teams for 15 cities in the USA. HOTCHKISS, MOORE, \& ZOBAY (2003) found significant positive employment effects on regions in Georgia (USA) that were affiliated with or close to the activities of the 1996 Atlanta Olympic Games, but they found no significant wage effects. BAADE \& MATHESON (2002) found that the 1996 Olympics had a much smaller impact. JASMAND \& MAENNIG (2008) found positive income effects for the German regions that hosted the 1972 Olympic Games. TU (2005) found significant positive 
effects from the FedEx Field (Washington) on real estate prices in the surrounding neighbourhood, as did AHLFELDT \& MAENNIG (2008) for three arenas in Berlin, Germany. Finally, CARLINO \& COULSON (2004) examined the 60 largest Metropolitan Statistical Areas (MSA) in the USA and found that having a National Football League (NFL) team allowed the cities to enjoy rents that were eight per cent higher but not higher wages. ${ }^{1}$ Other studies, particularly those by COATES \& HUMPHREYS (1999, 2000, 2001, 2003a, 2003b) and TEIGLAND (1999), have even indicated significant negative effects.

Among the studies that analyse mega-sporting events such as the Olympic Games, the FIFA World Cup, or the Super Bowl (in contrast to other studies on the effects of team sports or franchises), PORTER (1999), COATES \& HUMPHREYS (2002), BAADE, BAUMANN, \& MATHESON (2008a), COATES (2006), and MATHESON (2005) analysed the economic impact of the Super Bowl. The Olympic Games have been examined by BAADE \& MATHESON (2002), HOTCHKISS, MOORE, \& ZOBAY (2003), BAADE, BAUMANN, \& MATHESON (2008b), and LEEDS (2008). MATHESON (2006) and COATES \& HUMPHREYS (2008) provide an overview.

Only a few scholarly studies have analysed the economic impact of the FIFA World Cup. SZYMANSKI (2002) collected data on the twenty largest economies measured by current GDP over the last thirty years. Many of these countries have hosted the Olympic Games or the World Cup at least once in the past 30 years. Using a simple regression, he concluded that the growth of these countries was significantly lower during World Cup years. ${ }^{2}$ STERKEN (2006) found that World Cups have a positive effect but that this effect is quite limited. HAGN \& MAENNIG (2008) showed that the 1974 World Cup, which was held in Germany, did not generate significant short- or long-term employment effects in that country. BAADE \& MATHESON (2004) showed that, caused by the 1994 World Cup in the

1 In a comment, COATES, HUMPHREYS, \& ZIMBALIST (2006) showed that these results are not robust, for example, to the exclusion of extreme outliers. However, see also the reply to this comment by CARLINO \& COULSON (2006).

2 No significant effects at all were registered for the Olympic Games. 
USA, nine of the 13 host cities suffered decreased growth. Overall, the 13 locations suffered losses of over US\$9 billion. According to BAADE (1996), it would seem that long-term employment related to mega-sporting events is likely to be part-time, casual, low-skilled, and low-wage, thus not leading to an increase in fulltime jobs. KAVETSOS \& SZYMANSKI (2009) suggest that the construction phase may generate some employment. In an ex-post analysis, FEDDERSEN, GRÖTZINGER, \& MAENNIG (2009) and HAGN \& MAENNIG (2009) showed that the 2006 FIFA World Cup had no short-term employment effects.

The majority of studies thus only find insignificant or even negative effects from sports franchises, stadiums, and mega-events. After categorising the literature according to the degree of data disaggregation, one important methodological challenge should be discussed. First, one might ask what would have happened if the (public) money involved had been used for an alternative investment. Second, one might ask whether the observed impact is really caused by the treatment or whether one is really only detecting a coincidental macroeconomic shock. In the sports impact field, two main bodies of literature have been established to deal with these issues. Considering the first kind of counterfactual, amongst others, BAADE \& MATHESON (2001), COATES \& HUMPHREYS (2002) and MATHESON (2005) used panel data to compare predicted and observed values of economic indicators. Employing a growth model, for example, these studies used as a counterfactual the predicted economic growth for the treatment time using past development, which was then compared to the observed growth rate. The second body of impact analyses, including studies by FEDDERSEN, GRÖTZINGER, \& MAENNIG (2009), HAGN \& MAENNIG (2008, 2009), HOTCHKISS, MOORE, \& ZOBAY (2003), and JASMAND \& MAENNIG (2008), uses Difference-in-Difference (DD) approaches to isolate the impact of sports stadiums and events from pure macroeconomic shocks using additional geographic units as a control group. Here, development in host regions is compared to that in other regions. Both approaches depend on the assumption that a stable relationship between the predicted counterfactual and the true (not observable) counterfactual exists. However, even if this assumption does not apply completely, these approaches are preferable 
because the bias in ignoring counterfactuals altogether is definitely stronger than if the predicted counterfactual is not matched exactly.

The research design of the present study is based on an extended and flexible DD approach using employment data for Germany. This study is the first to analyse a sporting event outside the USA using regionalised and sectoralised data.

\section{Empirical Strategy}

\subsection{Data}

Quarterly data on employment for each county in Germany were obtained from the Federal Labour Agency ("Bundesagentur für Arbeit"). The data used are based on place of employment rather than place of residence. The Federal Labour Agency provides employment figures at the "Landkreise und kreisfreie Städte" level, which is the NUTS3 level in Germany and is comparable to the county-level in the USA. Furthermore, quarterly employment figures are provided for 60 different industries. On this spatially and temporally disaggregated level, data are available from the second quarter of 1999 to the fourth quarter of 2008 . Thus, the observation period consists of 38 quarters.

No data are available for some quarters and counties either because there were no people employed in the specific industry or because the data are subject to disclosure restrictions. Because continuous data are required for the DD analysis, only counties without any missing data were included in the empirical analysis. Additionally, due to some rare changes in county definitions, a few corrections were necessary. For example, a reformation of counties and county boundaries occurred in the federal state of Saxony in 2001. To guarantee continuous sequences, data for the old county definitions were applied to the new definitions. In the case of a change of boundary, the affected employment figures were 
summed to the lowest common spatial denominator even if this resulted in the "loss" of some geographical units. ${ }^{3}$

From the available 60 industries, eight were selected for analysis. The industries were chosen based on how plausible it was that they might be strongly affected by a mega-sporting event. The selected industry classifications are: Publishing, Communications Engineering, Construction, Wholesale Trade, Retail Trade, Hospitality, Land Transportation, and Culture, Sports, and Entertainment.

As the data used in this study are reported with quarterly frequency, they must be corrected for seasonal effects. The seasonally adjusted data were calculated using a quarterly dummy variable regression (BAUM, 2006, pp. 174-176; WOOLDRIDGE, 2009, p. 269). After conducting these regressions, the predicted residuals were taken as a seasonally adjusted time series.

Figure 1 indicates the geographical dimensions of German counties and the respective locations of World Cup venues. Figure 2(a) shows the development of overall seasonally adjusted employment in Germany, indexed to 1 in 199902 (the first available data point), separately for a) the group of venue counties and $b$ ) the control group, which consisted of the remaining counties in Germany. Figure 2(b) depicts the difference between the group averages (difference-in-mean). ${ }^{4}$ The data were averaged among the groups for every quarter and then normalised to the starting value in 199902. The two groups showed fairly similar relative development, although the venue group seemed to perform better until early 2002 . No visual evidence regarding the employment effect of the 2006 FIFA World Cup can be drawn. There is no short-term employment peak in the treatment group sequence. Also, no long-term effect can be identified based on visual inspection. No

3 Due to boundary changes in the course of the county re-divisions in the federal state of SaxonyAnhalt on July 1st, 2007, six counties had to be merged into two superordinate geographical units. Thus, the counties of "Dessau-Roßlau", "Anhalt-Bitterfeld", "Jerichower Land", and "Wittenberg" were merged into "Region 1", and the counties of "Harz" and "Salzlandkreis" were combined into "Region 2".

${ }^{4}$ Here, a smoothed trend line is included to represent a locally weighted regression (lowess). 
obvious shift can be seen either after the staging of the World Cup or after the announcement of Germany as the host country.

\section{Fig. 1 Venues of the 2006 FIFA World Cup}

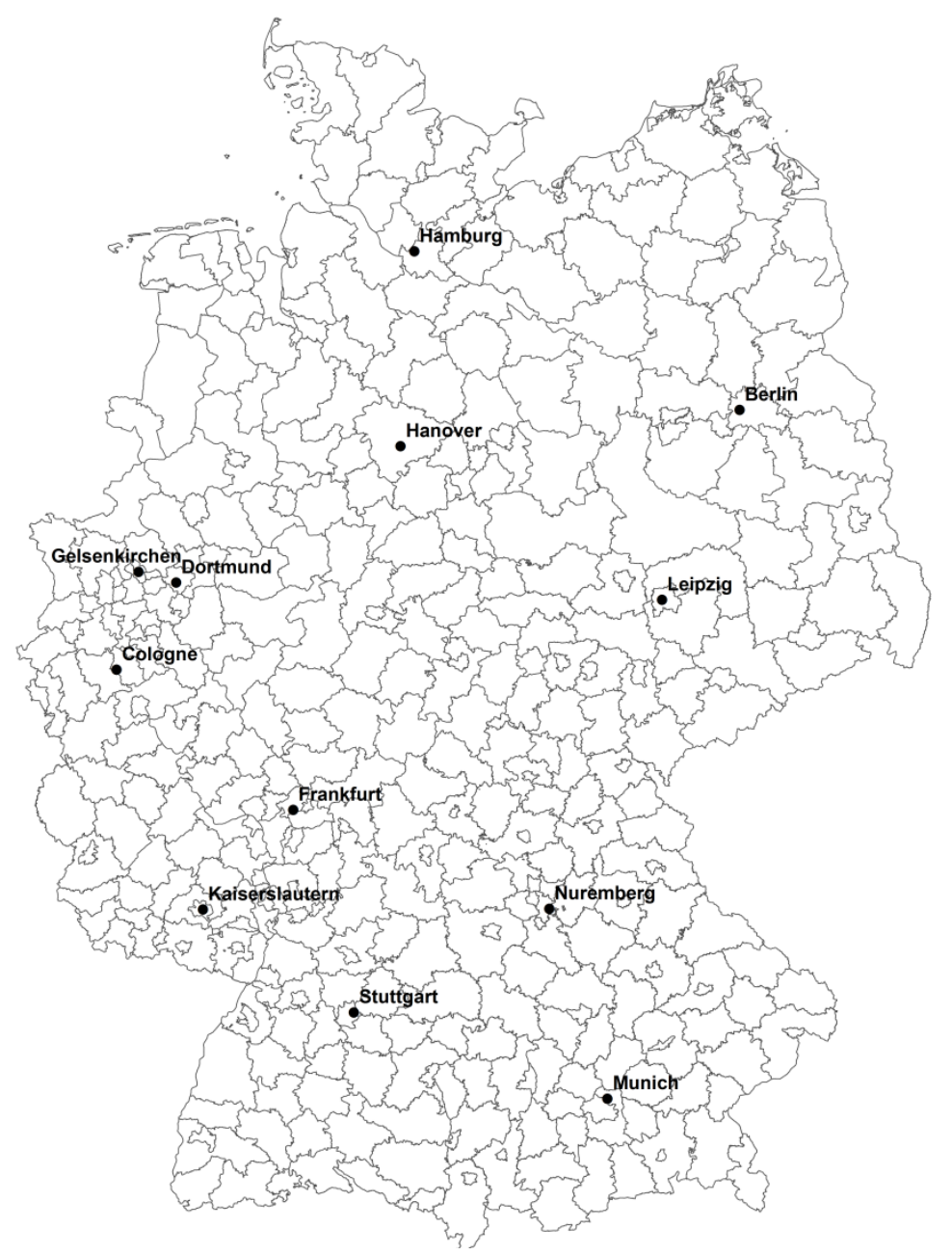

Notes: World Cup venues were geo-referenced according to their street addresses and marked by black dots. The regional units correspond to German counties according to their definition on December 31st, 2008 or to their lowest common spatial denominator. 
Fig. 2 Development of Seasonally Adjusted Employment (All Industries)

(a)

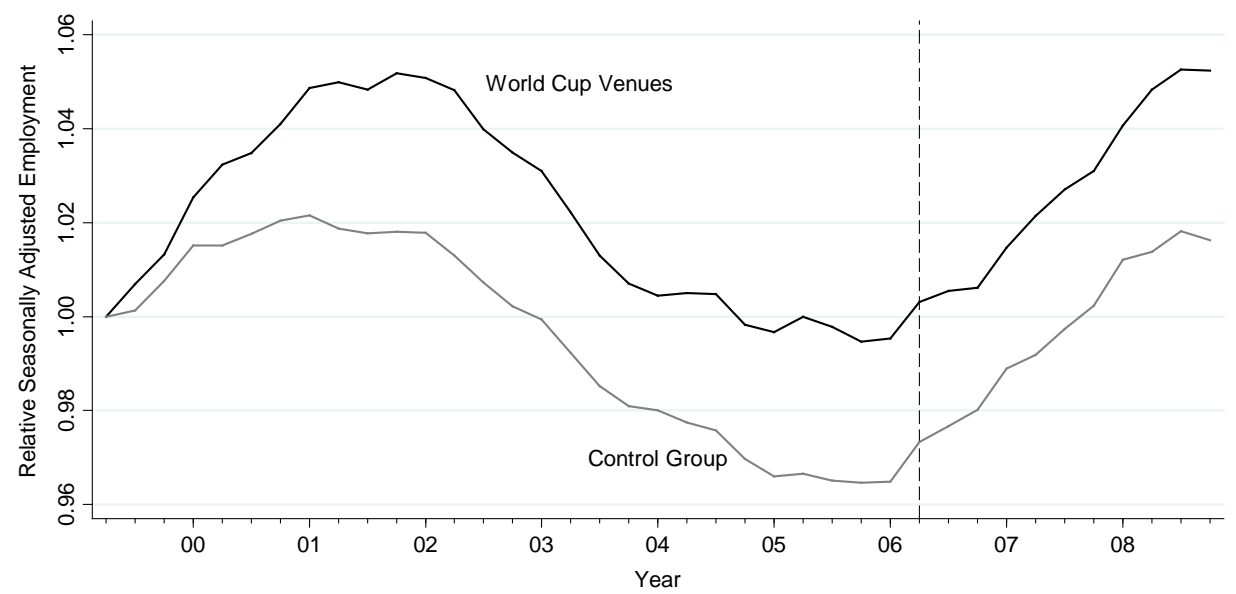

(b)

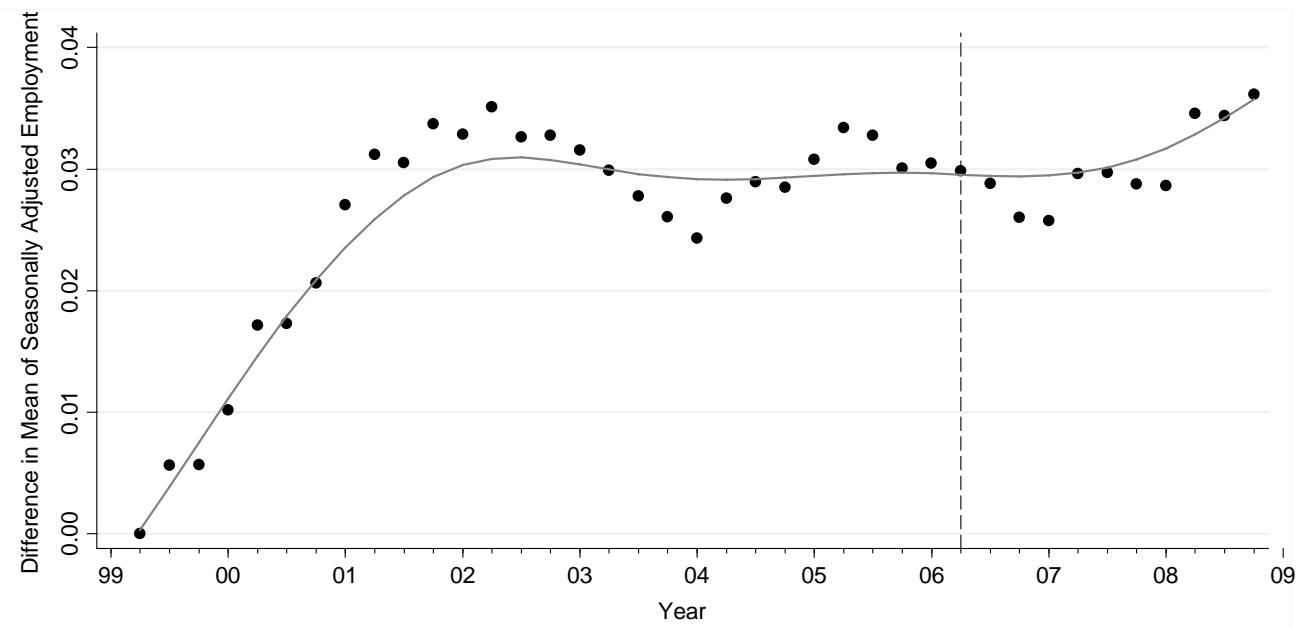

(c)

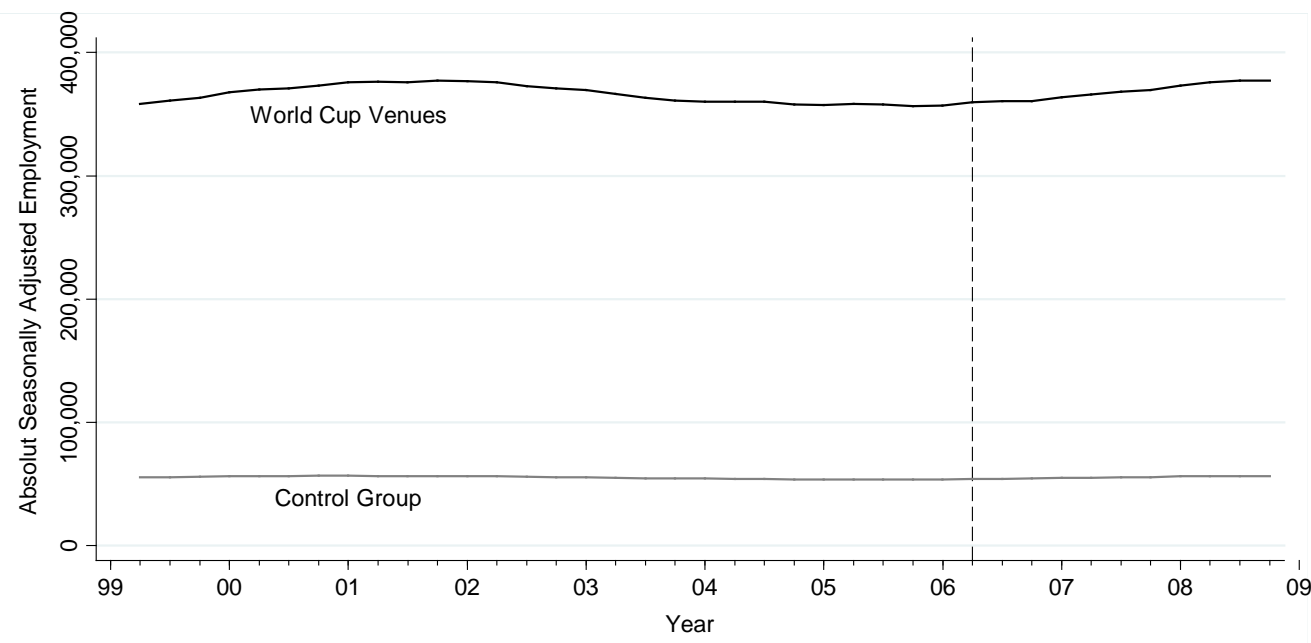

Notes: Quarterly employment was seasonally adjusted using a dummy variable regression. Employment figures are arithmetic means for both groups. The vertical line marks the quarter in which the 2006 FIFA World Cup was staged, i.e., 200602. 


\subsection{Econometric Model}

The aim of this paper is to examine the effect of the 2006 FIFA World Cup on sectoral employment in Germany. Difference-in-difference analysis (BERTRAND, DUFLO, \& MULLAINATHAN, 2004) or regression discontinuity designs (IMBENS \& LEMIEUX, 2008) are established approaches for the identification of treatment effects that occur at particular locations after a specific intervention. Common to both approaches is that one must compare the differences in outcome before and after an intervention for groups affected by the intervention to the difference for unaffected groups. Such analysis works best if the shock can be modelled discretionarily both with respect to location (treatment vs. control) and with respect to time (before and after the shock).

For our analysis, we employed a method introduced by DACHIS, DURANTON, \& TURNER (2010, pp. 9-13) in another research context. Let $t$ denote time, with $t=$ 200602 as the intervention point, $t<200602$ before the staging of the World Cup, and $t>200602$ afterwards. Let $i$ denote county-equivalent regional units ("Landkreise und kreisfreie Städte"). Then, two indicators based on time dimension $t$ and spatial dimension $i$ can be defined:

$$
\begin{aligned}
\chi^{P} & =\left\{\begin{array}{l}
1 \text { if } t \geq 2006 Q 2 \\
0 \text { else }
\end{array}\right. \\
\chi^{V} & =\left\{\begin{array}{l}
1 \text { if } i \in v \\
0 \text { else }
\end{array}\right.
\end{aligned}
$$

$\chi^{P}$ changes from zero to one for the quarter when the World Cup was held, and $\chi^{V}$ is one if a county belongs to the treatment group $v$. Here, the vector $v$ is comprised of the counties of the 12 World Cup venues (Berlin, Cologne, Dortmund, Frankfurt, Gelsenkirchen, Hamburg, Hannover, Kaiserslautern, Leipzig, Munich, Nuremberg, and Stuttgart).

Let $e(i, t)$ denote total employment at a particular location and time. Then, according to DACHIS, DURANTON, \& TURNER (2010), this function can be decomposed into five parts: (1) the function $l(i, t)$, a latent employment surface that is continuous in $i$ and $t$; (2) a jump in the employment surface that occurs in the quarter when the World Cup began: $\beta_{1} \chi^{P}$; (3) a jump in the employment surface 
that takes place in the venue counties only: $\beta_{2} \chi^{V}$; (4) an interaction effect for the former jumps: $\lambda \chi^{P} \chi^{V} ;(5)$ a mean zero error term.

Based on this notation, employment at location $i$ and time $t$ can be written as follows:

$$
e(i, t)=l(i, t)+\gamma \chi^{P}+\beta \chi^{V}+\lambda \chi^{P} \chi^{V}+\epsilon(i, t)
$$

Using the case of $l(i, t)=l(0,0)$, one can demonstrate how this strategy identifies the treatment effect of the 2006 FIFA World Cup. Here, all the variation in $e$ results from the discontinuities created by $\chi^{P}$ and $\chi^{V}$.

$$
e_{i, t}=l(0,0)+\gamma \chi^{P}+\beta \chi^{V}+\lambda \chi^{P} \chi^{V}+\epsilon_{i, t}
$$

Equation (4) is similar to the regression equation used by HOTCHKISS, MOORE, \& ZOBAY (2003) in analysing the 1996 Olympic Games. Apparently, two main problems arise in estimating equation (4). First, the assumption that $l$ is constant with respect to $i$ and $t$ seems to be restrictive, and it might be correct only for a small region around $l(0,0)$. If a larger variation in the surface $l(i, t)$ should be analysed, then variation in the latent employment surface can no longer be ignored. Consequently, equation (4) must be re-formulated as:

$$
e_{i, t}=l(0,0)+\gamma \chi^{P}+\beta \chi^{V}+\lambda \chi^{P} \chi^{V}+\mu_{i, t}
$$

The difference between the two equations is that, in equation (5), the variation in the latent employment surface is assigned to $\mu_{i, t}$. Consequently, the error term is $\mu_{i, t}=\epsilon_{i, t}+l_{i, t}-l(0,0)$. Assigning the variation to the error term is somewhat problematic if $\mu_{i, t}$ is correlated with either of the two indicators, $\chi^{P}$ or $\chi^{V}$. Thus, to obtain unbiased estimates, the following constraints must hold:

$$
\operatorname{Cov}\left(\mu_{i, t}, \chi^{P}\right)=0 \text { and } \operatorname{Cov}\left(\mu_{i, t}, \chi^{V}\right)=0 .
$$

Figure 2 shows that both the venue county group and the control group exhibited comparable employment trends. This suggests a positive correlation between $\chi^{P}$ and $\mu_{i, t}$. Furthermore, the bottom panel of Figure 2 shows a large difference between the employment levels of the venue county group and the control group. This observation leads to the suggestion that a positive correlation between $\chi^{V}$ 
and $\mu_{i, t}$ exists. As is obvious and was also pointed out by DACHIS, DURANTON, \& TURNER (2010, p. 12), correlations between the two indicator variables $\left(\chi^{P}, \chi^{V}\right)$ and the error term could bias estimates of $\gamma, \beta$, and, most importantly, $\lambda$. To address this problem, county fixed effects and time fixed effects were included in equation (3).

$$
e_{i, t}=\delta_{i}+\sum_{t} \beta_{t} \theta_{t}+\lambda \chi^{P} \chi^{V}+u_{i, t}
$$

where $\delta_{i}$ denotes a dummy variable for each single regional unit, i.e., county fixed effects, and $\theta_{t}$ is defined as a set of dummy variables for each quarter from 1999Q2 to 2008 Q 4 (i.e., time fixed effects). DACHIS, DURANTON, \& TURNER (2010, p. 12) use the Taylor series expansion of $l$ to explain how the specification of equation (4) helps to resolve problems caused by unobserved variation in the employment surface.

$$
l_{i t}=l(0,0)+\frac{\partial l}{\partial i} i_{t}+\frac{\partial l}{\partial t} t+\frac{1}{2} \frac{\partial^{2} l}{\partial i^{2}} i_{t}^{2}+\frac{1}{2} \frac{\partial^{2} l}{\partial t^{2}} t^{2}+\frac{\partial^{2} l}{\partial i \partial t} i_{t} t+O(3)
$$

In equation (4), the county fixed effects $\left(\delta_{i}\right)$ non-parametrically capture the proportion of variation in the employment surface $l$ that is solely attributable to region $i$. Hence,

$$
\delta_{i}=\sum_{k} \frac{1}{k !} \frac{\partial^{k} l}{\partial i} i_{t}^{k}
$$

where $\mathrm{k}$ is the order of the Taylor series expansion. Analogously, the time fixed effect $\left(\sum_{t} \theta_{t}\right)$ controls non-parametrically for all variation that depends solely on time $t$, and hence,

$$
\delta_{i}=\sum_{k} \frac{1}{k !} \frac{\partial^{k} l}{\partial t} t^{k}
$$

Therefore, in equation (4), the error term $u_{i, t}$ consists purely of noise and terms involving both $i$ and $t$ or, formally, $u_{i, t}=\frac{\partial^{2} l}{\partial i \partial t} i_{t} t+O(3)_{-i, t}+v_{i, t}$. Thus, $O(3)_{-i, t}$ denotes third- and higher-order terms in the Taylor series expansion that involve both $i$ and $t$.

Even if county fixed effects and time fixed effects capture all the variation that is purely attributable to temporal and spatial variation, estimates of equation (4) 
may be biased. In particular, if there are different employment trends for the venue counties and non-venue counties, confounded estimates of the impact of the World Cup might result if these trends are correlated with the indicator variables. To obtain unbiased estimates of $\lambda$ using equation (4), the following constraint must hold:

$$
\operatorname{Cov}\left(u_{i, t}, \chi^{P} \chi^{V}\right)=0
$$

A glance at the middle panel of Figure 2 suggests that, in fact, condition (8) does not hold for the data used. It is obvious that the two groups show different growth rates, such that divergence in the development of employment figures can be observed. To resolve this problem, spatially differentiated linear trends were considered. Accordingly, the augmented estimation equation that includes group-specific trends can be written as

$$
e_{i, t}=\delta_{i}+\sum_{t} \beta_{t} \theta_{t}+\alpha \tau^{V}+\lambda \chi^{P} \chi^{V}+v_{i, t}
$$

Here, $\tau^{V}$ is a trend for the treatment group consisting of the World Cup venue counties.

\subsection{Identifying the Treatment Group}

A common problem with all empirical analyses of a treatment, no matter whether they use Difference-in-Difference (DD) or Regression Discontinuity Design (RDD), is the exact definition of this treatment with respect to several inherent dimensions. It is rare that the analysed intervention is completely exogenous and can be distinguished clearly based on those dimensions. In the case of the 2006 FIFA World Cup, the treatment must be defined with regard to two dimensions: time and space.

Regarding the time dimension, the start of the treatment effect might be gradual because the intended (infrastructural) measures were introduced step by step, or it might be preceded by a kind of anticipation effect. Analogously, the duration of the effect might not be derived from theoretical considerations. Additionally, from a spatial point of view, the treatment might generate spillover effects for adjacent geographical units. 
Our empirical strategy takes these factors into account. With respect to the time dimension of the treatment, the intervention function was modelled in several ways. ${ }^{5}$ First, the intervention can be the result of a pure jump, i.e., a level shift occurring within the treatment group right after the event, to be captured by an effect as in equation (1). In this case, the estimation equation will be equation (4). Secondly, because such a sustainable effect is truly not supported by the empirical sports economics literature, the treatment effect should also be modelled as an impulse function, in which case it is assumed that the effect is only active during the staging of the World Cup. Thus, the impulse intervention is defined as

$$
\chi^{P}=\left\{\begin{array}{ll}
1 & \text { if } t=2006 Q 2 \\
0 & \text { else }
\end{array} .\right.
$$

Third and finally, the intervention should be modelled more flexibly to capture adjustment and/or anticipation effects. Thus, the treatment effect can be identified non-parametrically for a period starting with the announcement of the host of the 2006 World Cup (AHLFELDT, 2010).

$$
e_{i, t}=\delta_{i}+\sum_{t} \beta_{t} \theta_{t}+\alpha_{1} \tau^{V}+\sum_{t=2000 Q 2}^{2008 Q 4} \lambda_{t} \theta_{t} \chi^{V}+v_{i, t}
$$

Here, separate time dummies are made to interact with the respective treatment group dummy. This specification allows the treatment effect to vary freely over time.

Concerning the space dimension, surrounding areas might gain from the megaevent due to (1) avoidance strategies, e.g., tourists staying in hotels in the surrounding areas to avoid overcrowded and perhaps extremely expensive World Cup venue regions; and (2) spillover effects, i.e., the positive effects originally occurring in the main venue regions extending into surrounding regions. In this case, the effect occurring at a host city is transmitted into space and is thereby discounted according to the distance from the origin of the primary impact. Thus, one would expect that the effect would decay with growing distance from the

5 See, for example, ENDERS (1995, p. 273) for different intervention functions. 
World Cup venue counties. Figure 3 plots the absolute employment difference (top row) as well as the employment growth rate (bottom panel) and the distance to the closest venue county. No decaying relationship between employment and distance emerges, either for absolute employment differences or for employment growth. The lack of relationship also holds with one-year differences and growth rates instead of quarterly ones. World Cup spillover effects seem to have no impact on employment in Germany.

Fig. 3 Absolute Employment Difference and Growth Rates for Counties in Germany and Distance to the Closest World Cup Venue, 2005 and 2006
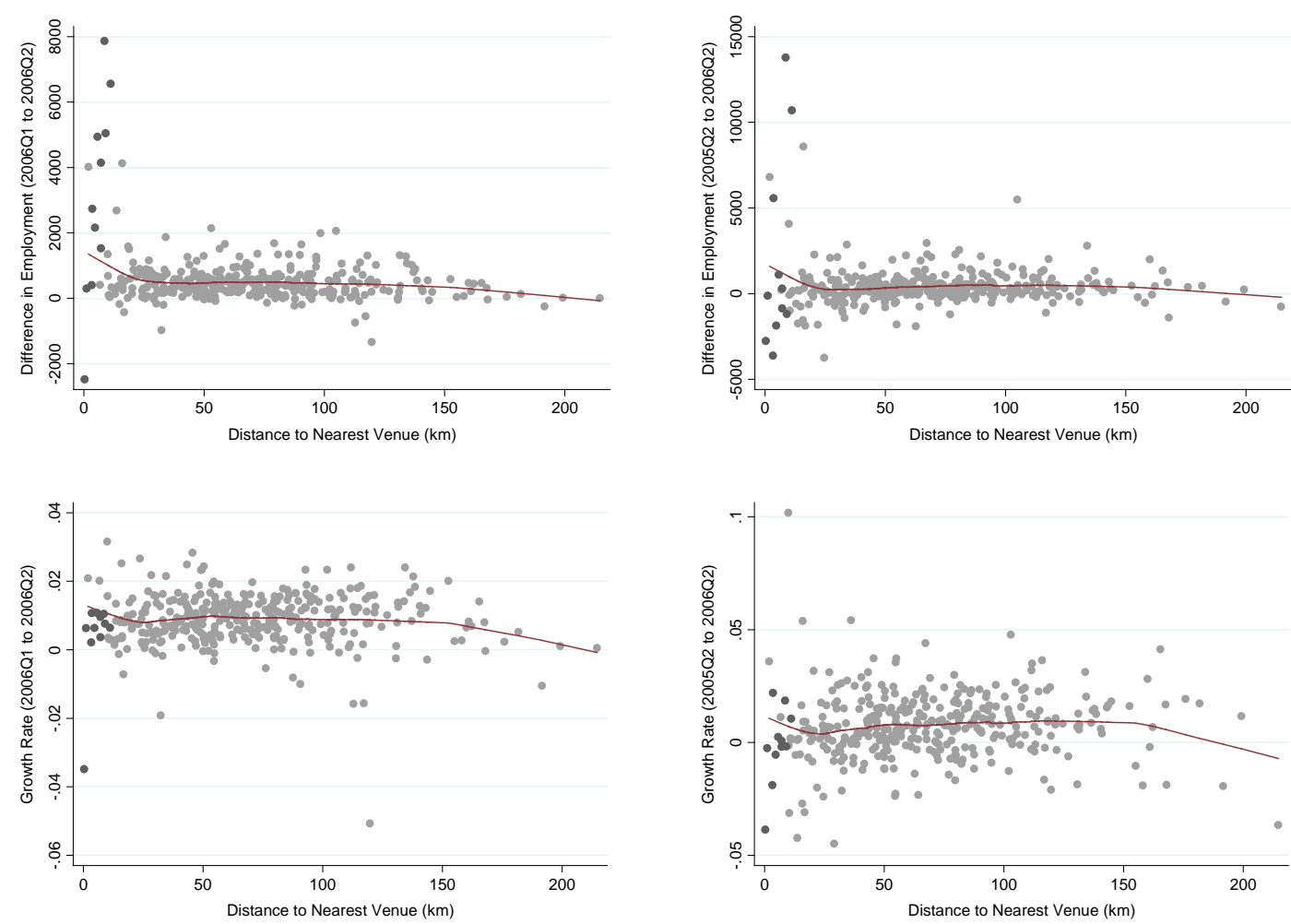

Notes: Employment differences (first row) and growth rates (second row) are based on the change from 2006 Q1 to 200602 (left column) and from 2005Q2 to 2006 2 (right column). Dark grey dots represent the World Cup venue counties, whereas other German counties are marked by light grey dots. The solid line is a lowess (smoothed) trend line that is calculated based on the non-venue counties only. 


\section{Results}

\subsection{Flexible Treatment}

First, the results for the most flexible approach according to equation (14) should be presented. This specification is characterised by interactions of the treatment group and time dummies. The results illustrated in Figure 4 show indices of the "treatment group"-"time dummy" interactives, i.e., the relative performance of the treatment group in a given month as revealed by the regression coefficients $\lambda_{t}$ (solid black line). Additionally, the corresponding $90 \%$ confidence intervals are presented (dashed black lines), as are a linear (dashed grey line) and a smoothed lowess (solid grey line) trend. Figure 5 shows the results for the eight different sectors that were presumed to be most heavily affected by the World Cup.

One of the aims of this approach is to allow for different effects throughout the observation period. The period beginning with the announcement of Germany as host of the 2006 FIFA World Cup in the second quarter of 2000 is particularly interesting. From the announcement date until the beginning of the World Cup, potential anticipation and adjustment processes could occur. The results for the aggregated employment data are ambiguous (Figure 4). For the entire observation period, the treatment group counties show superior performance relative to the control group. Starting in 2000, according to the lowess smoothed trend, an increase in relative performance can be seen. After reaching a kind of plateau, the lowess trend turns negative while relative performance remains positive. In the direct run-up to the World Cup and also in its aftermath, a reduction in positive treatment performance can be observed. Figure 5 indicates a negative trend in employment in World Cup venues relative to the remaining counties in Germany. Neither a positive persistent shift in the aftermath of the event nor a positive adjustment process in preparation for it can be observed from the flexible DD regressions for most of the industries examined. Overall, two exceptions may be pointed out. First, the "Hospitality" industry was the only one showing a positive trend. The corresponding indicator series in Figure 5 also provides evidence of a 
short-term effect. Besides a weak but clearly positive trend between 2002 and 2006, a peak can be observed in the second quarter of 2006, the month of the FIFA World Cup, indicating an additional employment boost that lasted only as long as the World Cup quarter. The construction industry might have also been affected by the World Cup. From early 2001 until 2004, the corresponding indicator series shows a weak but positive smoothed trend and the relative performance became positive. The trend then turns negative. This behaviour of the index series can be weakly interpreted as a consequence of the FIFA World Cup. Most of the stadium construction work induced by the World Cup was undertaken between early 2002 and early 2005 so the construction industry might have been stimulated by public subsidies. On the other hand, the public infrastructure investments might have been forwarded to some extent. In the aftermath of the main portion of the stadium construction work, there may have been a lack of public orders in the construction sector in World Cup areas, resulting in weaker performance for this sector. To our knowledge, this is the first time that this sort of theoretically assumed public order displacement effect of a mega-sporting event has been identified in an empirical analysis.

\section{Fig. 4 Quarterly Treatment Effects}

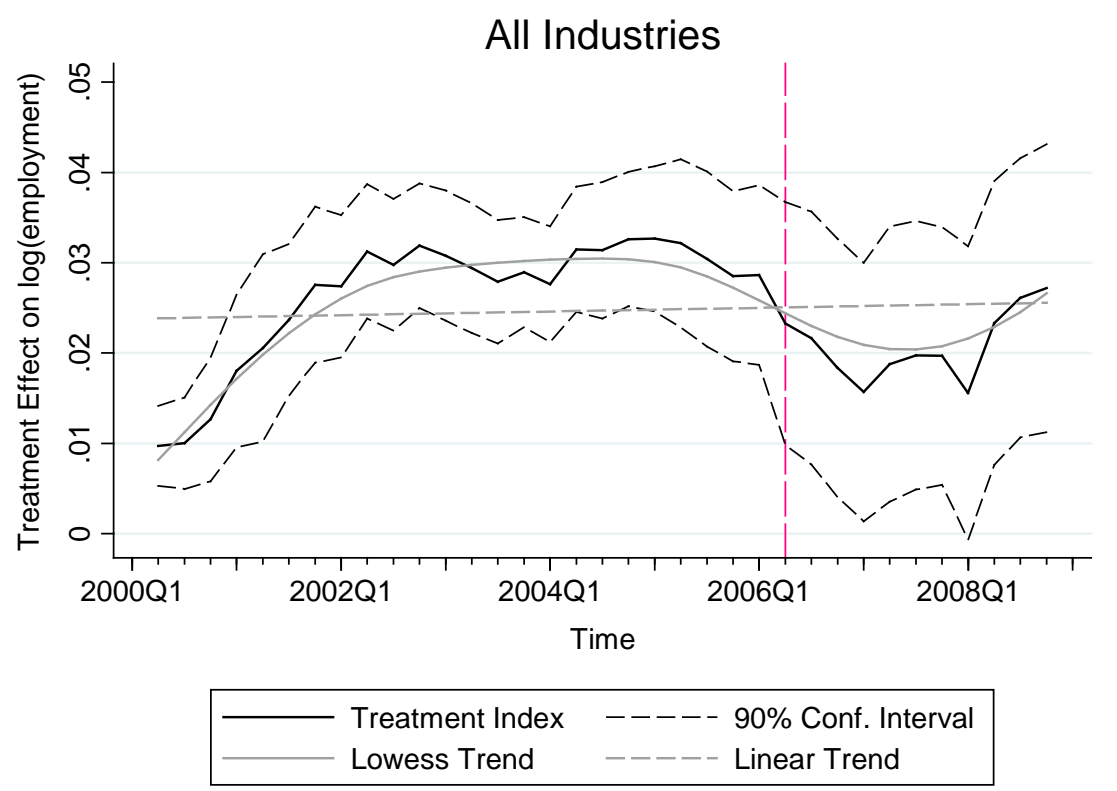

Notes: The treatment index is based on the corresponding interactive between quarterly fixed effects and the treatment group dummy. The treatment group is defined as all World Cup venues. The vertical line marks the quarter of the FIFA World Cup (200602). 
Fig. 5 Quarterly Treatment Effects by Sector
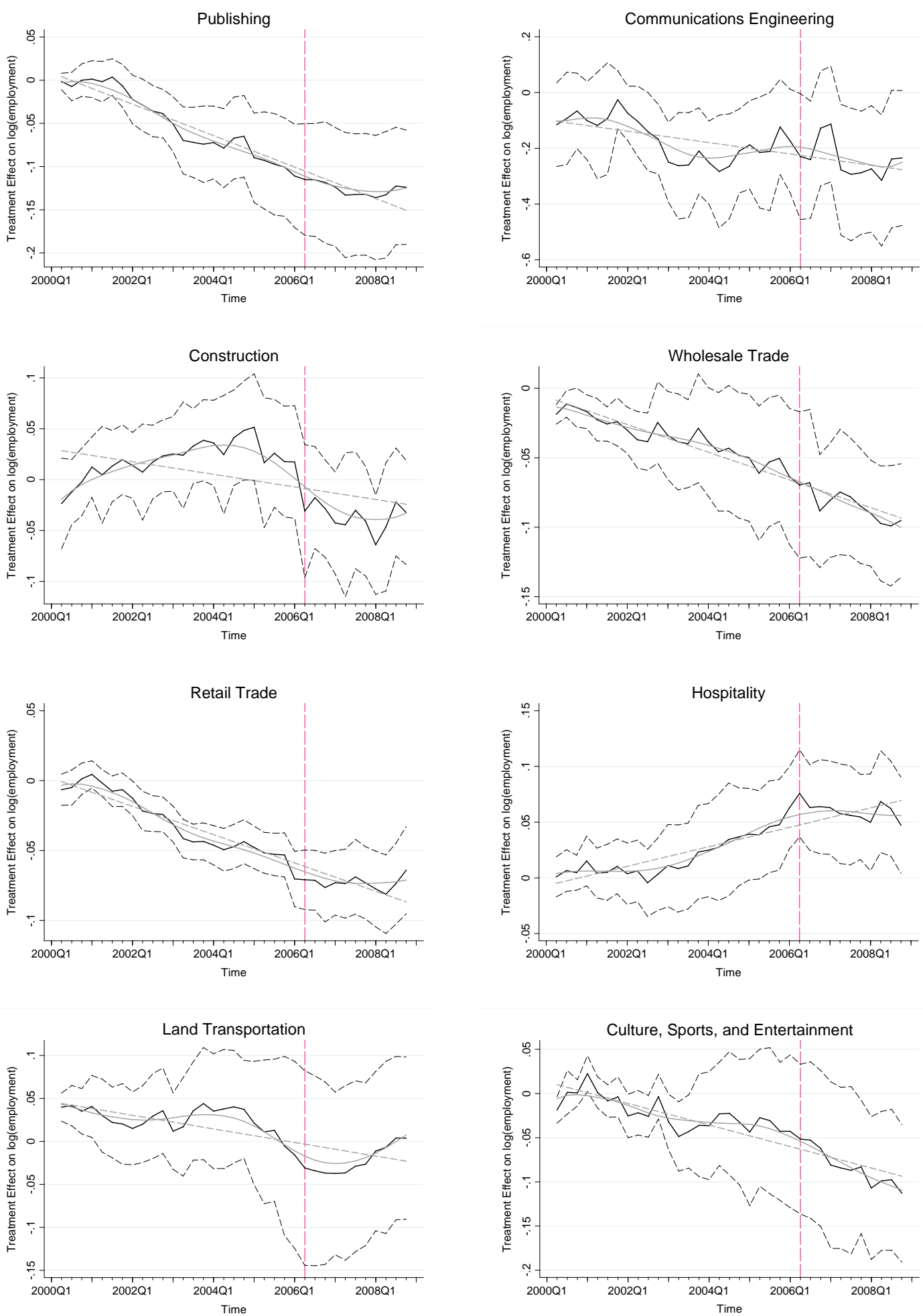

$$
\begin{aligned}
& \text { Treatment Index } \quad-----90 \% \text { Conf. Interval } \\
& \text { Lowess Trend } \\
& ------ \text { Linear Trend }
\end{aligned}
$$

Notes: The treatment index is based on the corresponding interactive between quarterly fixed effects and the treatment group dummy. The treatment group is defined as all World Cup venues. The vertical line marks the quarter of the FIFA World Cup (200602). 


\subsection{Persistent Treatment vs. Single Impulse}

Tables 2 to 4 display the results of the more traditional DD approach, applying a persistent level shift. The tables contain the estimates for the aggregated data as well as for the above-mentioned eight sectors. For each industry, two columns are presented. The first column refers to equation (7) and the second column is based on equation (12). As shown by BERTRAND, DUFLO, \& MULLAINATHAN (2004), DD models are frequently subject to serial correlation, which might cause overestimation of the significance of the "intervention" dummy. To check for such problems, we performed a LM test for serial correlations in a fixed-effects model, as suggested by BALTAGI (2001, pp. 94-95). ${ }^{6}$ Note that the test clearly rejects the null hypothesis of there being no serial correlation and thus the standard errors are corrected using an arbitrary variance-covariance matrix as recommended by BERTRAND, DUFLO, \& MULLAINATHAN (2004) in all estimations.

The variable of interest is $\chi^{P} \chi^{V}$. The hypothesis of the World Cup having no beneficial effect must be rejected in the case of a significant positive coefficient. The regressions for the aggregated employment data ("All”) display a similar structure that is also typical of many of the regressions based on sector-differentiated data. The persistent level shift dummy $\lambda$ is significant in the first column for each specific sector. However, as mentioned above, different spatial trends between the two groups might hurt condition (11). If a treatment group-specific trend is included in the regression, $\lambda$ becomes insignificant (second column for each sector) and no persistent effect of the World Cup can be detected. There are only two sectors for which the hypothesis of there being no beneficial effect must be rejected. The first is the hospitality sector, for which a significantly positive effect of the World Cup can be found in the regression without a trend. Including a trend leads to an insignificant shift dummy, but the trend coefficient is insignificant itself. In the case of the construction industry, $\lambda$ is significantly negative, and the coefficient remains significant after the inclusion of a (insignificant) trend, imply-

6 The LM test statistic is $L M_{5}=\sqrt{N T^{2} /(T-1)\left(\tilde{v}^{\prime} \tilde{v}_{-1} / \tilde{v}^{\prime} \tilde{v}\right)}$, which is asymptotically distributed as $N(0,1)$. 
ing that a persistent negative level shift occurred in the construction industry in the aftermath of the $\mathbf{2 0 0 6}$ World Cup. This corroborates the evidence of a displacement effect of public orders in the venue counties, as was suggested by the results indicated in the previous section.

Tab. 1 Treatment Effect: Persistent Level Shift

\begin{tabular}{|c|c|c|c|c|c|c|}
\hline \multirow{2}{*}{$\begin{array}{l}\text { Industry } \\
\text { Constant }\end{array}$} & \multicolumn{2}{|c|}{ All } & \multicolumn{2}{|c|}{ Publishing } & \multicolumn{2}{|c|}{$\begin{array}{l}\text { Communications } \\
\text { Engineering }\end{array}$} \\
\hline & $\begin{array}{c}10.768^{* * *} \\
(0.003)\end{array}$ & $\begin{array}{c}10.764^{* * *} \\
(0.002)\end{array}$ & $\begin{array}{c}6.095^{* * *} \\
(0.010)\end{array}$ & $\begin{array}{c}6.111^{* * *} \\
(0.010)\end{array}$ & $\begin{array}{c}5.779^{* * *} \\
(0.036)\end{array}$ & $\begin{array}{c}5.828^{* * *} \\
(0.038)\end{array}$ \\
\hline$\chi^{P} \chi^{V}$ & $\begin{array}{c}-0.023^{* * *} \\
(0.008)\end{array}$ & $\begin{array}{l}-0.003 \\
(0.008)\end{array}$ & $\begin{array}{c}-0.082^{* * *} \\
(0.031)\end{array}$ & $\begin{array}{l}-0.002 \\
(0.017)\end{array}$ & $\begin{array}{l}-0.087 \\
(0.096)\end{array}$ & $\begin{array}{c}0.069 \\
(0.100)\end{array}$ \\
\hline$\tau^{V}$ & - & $\begin{array}{l}0.001^{* * *} \\
\left(2.00 \mathrm{e}^{-4}\right)\end{array}$ & - & $\begin{array}{c}-0.004^{* * *} \\
(0.002)\end{array}$ & - & $\begin{array}{l}-0.008^{*} \\
(0.005)\end{array}$ \\
\hline$R^{2}$ & 0.998 & 0.998 & 0.983 & 0.983 & 0.902 & 0.902 \\
\hline $\operatorname{adj} . R^{2}$ & 0.998 & 0.998 & 0.983 & 0.983 & 0.899 & 0.899 \\
\hline $\mathrm{N} \times \mathrm{T}$ & 13,494 & 13,494 & 13,494 & 13,494 & 6,970 & 6,970 \\
\hline LM5 & 106.848 & 106.841 & 104.493 & 104.494 & 69.684 & 69.678 \\
\hline \% Effect & $2.3 \%$ & no & $8.6 \%$ & no & no & no \\
\hline
\end{tabular}


Tab. 2 Treatment Effect: Persistent Level Shift (cont. I)

\begin{tabular}{|c|c|c|c|c|c|c|}
\hline \multirow{2}{*}{$\begin{array}{l}\text { Industry } \\
\text { Constant }\end{array}$} & \multicolumn{2}{|c|}{ Construction } & \multicolumn{2}{|c|}{ Wholesale Trade } & \multicolumn{2}{|c|}{ Retail Trade } \\
\hline & $\begin{array}{c}8.270^{* * *} \\
(0.007)\end{array}$ & $\begin{array}{c}8.266^{* * *} \\
(0.009)\end{array}$ & $\begin{array}{c}7.627^{* * *} \\
(0.007)\end{array}$ & $\begin{array}{c}7.636^{* * *} \\
(0.008)\end{array}$ & $\begin{array}{c}8.226^{* * *} \\
(0.004)\end{array}$ & $\begin{array}{c}8.236^{* * *} \\
(0.003)\end{array}$ \\
\hline$\chi^{P} \chi^{V}$ & $\begin{array}{c}-0.055^{* * *} \\
(0.021)\end{array}$ & $\begin{array}{c}-0.077^{* * *} \\
(0.017)\end{array}$ & $\begin{array}{l}-0.057 \\
(0.018)\end{array}$ & $\begin{array}{l}-0.012 \\
(0.024)\end{array}$ & $\begin{array}{c}-0.054^{* * *} \\
(0.016)\end{array}$ & $\begin{array}{l}-0.006 \\
(0.018)\end{array}$ \\
\hline$\tau^{V}$ & - & $\begin{array}{c}0.001 \\
(0.001)\end{array}$ & - & $\begin{array}{l}-0.002^{*} \\
(0.001)\end{array}$ & - & $\begin{array}{c}-0.002^{* * *} \\
\left(3.84 \mathrm{e}^{-4}\right)\end{array}$ \\
\hline $\mathrm{R}^{2}$ & 0.985 & 0.985 & 0.991 & 0.991 & 0.994 & 0.994 \\
\hline $\operatorname{adj} . R^{2}$ & 0.985 & 0.985 & 0.991 & 0.991 & 0.994 & 0.994 \\
\hline $\mathrm{N} \times \mathrm{T}$ & 13,494 & 13,494 & 13,494 & 13,494 & 13,494 & 13,494 \\
\hline LM5 & 103.355 & 103.335 & 103.971 & 103.988 & 105.461 & 105.477 \\
\hline$\%$ Effect & $5.7 \%$ & $8.0 \%$ & no & no & $5.5 \%$ & no \\
\hline
\end{tabular}

Tab. 3 Treatment Effect: Persistent Level Shift (cont. II)

\begin{tabular}{lcccccc}
\hline Industry & \multicolumn{2}{c}{ Hospitality } & \multicolumn{2}{c}{ Land Transportation } & \multicolumn{2}{c}{$\begin{array}{c}\text { Culture, Sports, and } \\
\text { Entertainment }\end{array}$} \\
\hline Constant & $\begin{array}{c}7.068^{* * *} \\
(0.005)\end{array}$ & $\begin{array}{c}7.061^{* * *} \\
(0.006)\end{array}$ & $\begin{array}{c}6.514^{* * *} \\
(0.009)\end{array}$ & $\begin{array}{c}6.513^{* * *} \\
(0.013)\end{array}$ & $\begin{array}{c}5.521^{* * *} \\
(0.012)\end{array}$ & $\begin{array}{c}5.531^{* * *} \\
(0.014)\end{array}$ \\
& $0.044^{* * *}$ & 0.012 & -0.051 & -0.055 & -0.069 & -0.025 \\
$\chi^{P} \chi^{V}$ & $(0.016)$ & $(0.018)$ & $(0.051)$ & $(0.035)$ & $(0.040)$ & $(0.015)$ \\
& & 0.002 & & $2.10 \mathrm{E}-4$ & & -0.002 \\
\multicolumn{1}{c}{$\tau^{V}$} & - & $(0.001)$ & - & $(0.002)$ & & $(0.002)$ \\
$\mathrm{R}^{2}$ & 0.993 & 0.993 & 0.984 & 0.984 & 0.979 & 0.979 \\
adj. R & 0.993 & 0.993 & 0.984 & 0.984 & 0.978 & 0.978 \\
$\mathrm{~N} \times \mathrm{T}$ & 13,455 & 13,455 & 13,494 & 13,494 & 13,489 & 13,489 \\
LM5 & 100.560 & 100.564 & 101.766 & 101.760 & 87.840 & 87.840 \\
$\%$ Effect & $4.5 \%$ & no & no & no & no & no \\
\hline
\end{tabular}

Notes: " $p<0.01, " p<0.05, \quad p<0.10$. Robust standard errors, which are computed using an arbitrary variance-covariance matrix as suggested by BERTRAND, DUFLO, \& MULLAINATHAN (2004, pp. 270-272), are given in parentheses. The percentage effect is calculated as suggested by HALVORSEN \& PALMOUIST (1980). 
In summary, the tests for persistent level shifts hardly showed any impact of the 2006 FIFA World Cup on disaggregated employment, with the minor exception of the hospitality sector.

To test for a short-term impact, we use equation (13). Table 4 summarises these results. The treatment dummy, which takes the value of one during the World Cup (200602) and zero otherwise, is insignificant for most of the regressions, indicating no common short-term effect. In the regressions without a trend, three sectors (publishing, retail trade, and hospitality) display a significant coefficient. Including a trend implies insignificant coefficients for all sectors except the hospitality sector. This result confirms the insights generated using the flexible approach. In conclusion, a significant peak in hospitality employment can be attested to for the quarter during which the 2006 World Cup was held. Because the DD approach controls for counterfactuals, this peak can be associated with the World Cup.

Tab. 4 Treatment Effect: Single Impulse

\begin{tabular}{|c|c|c|c|c|c|c|}
\hline \multirow{2}{*}{$\begin{array}{l}\text { Industry } \\
\text { Constant }\end{array}$} & \multicolumn{2}{|c|}{ All } & \multicolumn{2}{|c|}{ Publishing } & \multicolumn{2}{|c|}{$\begin{array}{l}\text { Communications } \\
\text { Engineering }\end{array}$} \\
\hline & $\begin{array}{c}10.768^{* * *} \\
(0.003)\end{array}$ & $\begin{array}{c}10.767^{* * *} \\
(0.003)\end{array}$ & $\begin{array}{c}6.095^{* * *} \\
(0.010)\end{array}$ & $\begin{array}{c}6.112^{* * *} \\
(0.010)\end{array}$ & $\begin{array}{l}5.779 * * * \\
(0.036)\end{array}$ & $\begin{array}{l}5.815^{* * *} \\
(0.036)\end{array}$ \\
\hline$\chi^{P} \chi^{V}$ & $\begin{array}{c}0.001 \\
(0.005)\end{array}$ & $\begin{array}{l}-0.002 \\
(0.003)\end{array}$ & $\begin{array}{l}-0.046^{* *} \\
(0.021)\end{array}$ & $\begin{array}{l}-0.008 \\
(0.011)\end{array}$ & $\begin{array}{l}-0.041 \\
(0.147)\end{array}$ & $\begin{array}{c}0.014 \\
(0.156)\end{array}$ \\
\hline$\tau^{V}$ & - & $\begin{array}{c}3.08 \mathrm{e}^{-4} \\
\left(2.89 \mathrm{e}^{-4}\right)\end{array}$ & - & $\begin{array}{c}-0.004^{* * *} \\
(0.002)\end{array}$ & - & $\begin{array}{l}-0.006 \\
(0.004)\end{array}$ \\
\hline $\mathrm{R}^{2}$ & 0.998 & 0.998 & 0.983 & 0.983 & 0.902 & 0.902 \\
\hline $\operatorname{adj} . R^{2}$ & 0.998 & 0.998 & 0.983 & 0.983 & 0.899 & 0.899 \\
\hline $\mathrm{N} \times \mathrm{T}$ & 13,494 & 13,494 & 13,494 & 13,494 & 6,970 & 6,970 \\
\hline LM5 & 106.841 & 106.849 & 104.512 & 104.494 & 69.688 & 69.682 \\
\hline \% Effect & no & no & $4.7 \%$ & no & No & no \\
\hline
\end{tabular}

Notes: "'p $p<0.01, "{ }^{\prime \prime} p<0.05, " p<0.10$. Robust standard errors, which are computed using an arbitrary variance-covariance matrix as suggested by BERTRAND, DUFLO, \& MULLAINATHAN (2004, pp. 270-272), are given in parentheses. The percentage effect is calculated as suggested by HALVORSEN \& PALMQUUIST (1980). 
Tab. 5 Treatment Effect: Single Impulse (cont. I)

\begin{tabular}{|c|c|c|c|c|c|c|}
\hline \multirow{2}{*}{$\begin{array}{l}\text { Industry } \\
\text { Constant }\end{array}$} & \multicolumn{2}{|c|}{ Construction } & \multicolumn{2}{|c|}{ Wholesale Trade } & \multicolumn{2}{|c|}{ Retail Trade } \\
\hline & $\begin{array}{c}8.270^{* * *} \\
(0.007)\end{array}$ & $\begin{array}{c}8.275^{* * *} \\
(0.008)\end{array}$ & $\begin{array}{c}7.627^{* * *} \\
(0.007)\end{array}$ & $\begin{array}{c}7.638^{* * *} \\
(0.007)\end{array}$ & $\begin{array}{c}8.226^{* * *} \\
(0.004)\end{array}$ & $\begin{array}{c}8.237^{* * *} \\
(0.004)\end{array}$ \\
\hline$\chi^{P} \chi^{V}$ & $\begin{array}{l}-0.039 \\
(0.023)\end{array}$ & $\begin{array}{l}-0.027 \\
(0.019)\end{array}$ & $\begin{array}{c}-0.022 \\
(0.021)\end{array}$ & $\begin{array}{c}0.003 \\
(0.016)\end{array}$ & $\begin{array}{c}-0.033^{* * *} \\
(0.011)\end{array}$ & $\begin{array}{l}-0.009 \\
(0.009)\end{array}$ \\
\hline$\tau^{V}$ & - & $\begin{array}{l}-0.001 \\
(0.001)\end{array}$ & - & $\begin{array}{c}-0.003^{* * *} \\
(0.001)\end{array}$ & - & $\begin{array}{c}-0.003^{* * *} \\
(0.001)\end{array}$ \\
\hline $\mathrm{R}^{2}$ & 0.985 & 0.985 & 0.991 & 0.991 & 0.994 & 0.994 \\
\hline $\operatorname{adj} . R^{2}$ & 0.985 & 0.985 & 0.991 & 0.991 & 0.994 & 0.994 \\
\hline $\mathrm{N} \times \mathrm{T}$ & 13,494 & 13,494 & 13,494 & 13,494 & 13,494 & 13,494 \\
\hline LM5 & 103.377 & 103.382 & 103.994 & 103.988 & 105.526 & 105.475 \\
\hline$\%$ Effect & no & no & no & no & $3.4 \%$ & no \\
\hline
\end{tabular}

Tab. 6 Treatment Effect: Single Impulse (cont. II)

\begin{tabular}{|c|c|c|c|c|c|c|}
\hline \multirow{2}{*}{$\begin{array}{l}\text { Industry } \\
\text { Constant }\end{array}$} & \multicolumn{2}{|c|}{ Hospitality } & \multicolumn{2}{|c|}{ Land Transportation } & \multicolumn{2}{|c|}{$\begin{array}{c}\text { Culture, Sports and } \\
\text { Entertainment }\end{array}$} \\
\hline & $\begin{array}{c}7.068^{* * *} \\
(0.005)\end{array}$ & $\begin{array}{l}7.060^{* * *} \\
(0.006)\end{array}$ & $\begin{array}{c}6.514^{* * *} \\
(0.009)\end{array}$ & $\begin{array}{c}6.520^{* * *} \\
(0.013)\end{array}$ & $\begin{array}{c}5.521^{* * *} \\
(0.012)\end{array}$ & $\begin{array}{l}5.534^{* * *} \\
(0.014)\end{array}$ \\
\hline$\chi^{P} \chi^{V}$ & $\begin{array}{c}0.050^{* * *} \\
(0.009)\end{array}$ & $\begin{array}{c}0.031^{* * *} \\
(0.006)\end{array}$ & $\begin{array}{l}-0.050 \\
(0.048)\end{array}$ & $\begin{array}{l}-0.037 \\
(0.029)\end{array}$ & $\begin{array}{l}-0.016 \\
(0.030)\end{array}$ & $\begin{array}{c}0.012 \\
(0.012)\end{array}$ \\
\hline$\tau^{V}$ & - & $\begin{array}{l}0.002^{* *} \\
(0.001)\end{array}$ & - & $\begin{array}{l}-0.001 \\
(0.002)\end{array}$ & - & $\begin{array}{l}-0.003 \\
(0.002)\end{array}$ \\
\hline $\mathrm{R}^{2}$ & 0.993 & 0.993 & 0.984 & 0.984 & 0.979 & 0.979 \\
\hline $\operatorname{adj} . R^{2}$ & 0.993 & 0.993 & 0.984 & 0.984 & 0.978 & 0.978 \\
\hline $\mathrm{N} \times \mathrm{T}$ & 13,455 & 13,455 & 13,494 & 13,494 & 13,489 & 13,489 \\
\hline LM5 & 100.615 & 100.568 & 101.796 & 101.784 & 87.859 & 87.839 \\
\hline$\%$ Effect & $5.1 \%$ & $3.2 \%$ & no & no & No & no \\
\hline
\end{tabular}

Notes: " $p<0.01, " p<0.05, \quad p<0.10$. Robust standard errors, which are computed using an arbitrary variance-covariance matrix as suggested by BERTRAND, DUFLO, \& MULLAINATHAN (2004, pp. 270-272), are given in parentheses. The percentage effect is calculated as suggested by HALVORSEN \& PALMOUIST (1980). 


\section{Conclusion}

This study is the first to test for employment effects of the 2006 World Cup on the basis of data that are regionalised and sectoralised. To our knowledge, it is also the first study to operate on this basis for a sports event outside the USA. Studies of the 2006 World Cup that used regionalised data on a macro level could not identify any employment effects (HAGN \& MAENNIG (2009) and FEDDERSEN, GRÖTZINGER, \& MAENNIG (2009)).

Two different DD approaches were employed: a flexible partially non-parametric model and a more traditional DD model. Both approaches reject the hypothesis of a long-term and persistent employment boost caused by the 2006 World Cup. Even a short-term effect lasting only one quarter cannot be generally confirmed. Only the hospitality sector, which is one of the industries predestined to be affected by a mega-sporting event, showed a significantly positive short-term effect. In this sector, in the second quarter of 2006, an employment increase of $3.2 \%$ was observed. This effect can be translated into about 2,000 additional jobs within the German hospitality industries (hotels, food services, and drinking establishments), a far cry from the five-digit employment effects predicted in most ex-ante studies. With regard to the construction sector, both DD approaches suggest that the venue counties' construction industry gained in the run-up phase of the event. However, beginning with the end of the infrastructural measures in the pre-event period, an employment decrease was observed. Combining these two findings, one might suggest that a displacement effect of public (infrastructure) investment occurred.

In summary, it appears that even the sectorally, temporally and geographically localised positive employment effects of the 2006 World Cup were small. This conclusion is in line with most of the scholarly ex-post analyses that have used macro data, sectoral data, and/or regional data. 


\section{Literature}

AHLFELDT, G. M. (2010). Blessing or Curse? Appreciation, Amenities and Resistance around the Berlin "Mediaspree". Hamburg Contemporary Economic Discussions, 32.

ALLMERS, S., \& MAENNIG, W. (2009). Economic Impacts of the FIFA Soccer World Cups in France 1998, Germany 2006, and Outlook for South Africa 2010. Eastern Economic Journal, 35(4), 500-519.

BAADE, R. A. (1987). Is There an Economic Rationale for Subsidizing Sports Stadiums? Heartland Policy Study 13.

BAADE, R. A. (1996). Professional Sports as Catalysts for Metropolitan Economic Development. Journal of Urban Affairs, 18(1), 1-17.

BAADE, R. A., BAUMANN, R. W., \& MATHESON, V. A. (2008a). Selling the Game: Estimating the Economic Impact of Professional Sports through Taxable Sales. Southern Economic Journal, 74(3), 794-810.

BAADE, R. A., BAUMANN, R. W., \& MATHESON, V. A. (2008b). Slippery Slope? Assessing the Economic Impact of the 2002 Winter Olympic Games in Salt Lake City, Utah. Région \& Développement, 31, 79-89.

BAADE, R. A., \& DYE, R. F. (1988). An Analysis of the Economic Rational for Public Subsidization of Sports Stadiums. Annals of Regional Science, 22(2), 37-47.

BAADE, R. A., \& DYE, R. F. (1990). The Impact of Stadiums and Professional Sports on Metropolitan Area Development. Growth and Change, 21(2), 1-14.

BAADE, R. A., \& MATHESON, V. A. (2001). Home Run or Wild Pitch? Assessing the Economic Impact of Major League Baseball's All-Star Game. Journal of Sports Economics, 2(4), 307-327.

BAADE, R. A., \& MATHESON, V. A. (2002). Bidding for the Olympics: Fool's Gold? In C. P. Barros, M. Ibrahimo, \& S. Szymanski (Eds.), Transatlantic Sport: The Comparative Economics of North American and European Sports (pp. 127-151). Cheltenham, U.K. and Northampton, Mass.: Edward Elgar.

BAADE, R. A., \& MATHESON, V. A. (2004). The Quest for the Cup: Assessing the Economic Impact of the World Cup. Regional Studies, 38(4), 343-354.

BALTAGI, B. H. (2001). Econometric Analysis of Panel Data (2 ed.). New York: Wiley \& Sons.

BAUM, C. F. (2006). An Introduction to Modern Econometrics Using Stata. College Station: Stata Press.

BERTRAND, M., DUFLO, E., \& MULLAINATHAN, S. (2004). How Much Should We Trust Differences-in-Differences Estimates? Quarterly Journal of Economics, 119(1), 249-275.

BRENKE, K., \& WAGNER, G. G. (2007). Zum volkswirtschaftlichen Wert der FußballWeltmeisterschaft 2006 in Deutschland. DIW Berlin Research Notes, 19.

CARLINO, G., \& COULSON, N. E. (2004). Compensating Differentials and the Social Benefits of the NFL. Journal of Urban Economics, 56(1), 25-50.

CARLINO, G., \& COULSON, N. E. (2006). Compensating Differentials and the Social Benefit of the NFL: Reply. Journal of Urban Economics, 60(1), 132-138.

COATES, D. (2006). The Tax Benefits of Hosting the Super Bowl and the MLB All-Star Game: The Houston Experience. International Journal of Sport Finance, 1(4), 239-252. 
COATES, D., \& HUMPHREYS, B. R. (1999). The Growth Effects of Sport Franchises, Stadia, and Arenas. Journal of Policy Analysis and Management, 18(4), 601-624.

COATES, D., \& HUMPHREYS, B. R. (2000). The Stadium Gambit and Local Economic Development. The Cato Review of Business and Government, 23(2), 15-20.

COATES, D., \& HUMPHREYS, B. R. (2001). The Economic Consequences of Professional Sports Strikes and Lockouts. Southern Economic Journal, 67(3), 737-747.

COATES, D., \& HUMPHREYS, B. R. (2002). The Economic Impact of Postseason Play in Professional Sports. Journal of Sports Economics, 3(3), 291-299.

COATES, D., \& HUMPHREYS, B. R. (2003a). The Effect of Professional Sports on Earnings and Employment in the Services and Retail Sectors in US Cities. Regional Science and Urban Economics, 33(2), 175-198.

COATES, D., \& HUMPHREYS, B. R. (2003b). Professional Sports Facilities, Franchises and Urban Economic Development. Public Finance and Management, 3(3), 335-357.

COATES, D., \& HUMPHREYS, B. R. (2008). Do Economists Reach a Conclusion on Subsidies for Sports Franchises, Stadiums, and Mega-Events? Econ Journal Watch, 5(3), 294-315.

COATES, D., HUMPHREYS, B. R., \& ZIMBALIST, A. (2006). Compensating Differentials and the Social Benefits of the NFL: A Comment. Journal of Urban Economics, 60(1), 124131.

DACHIS, B., DURANTON, G., \& TURNER, M. A. (2010). The Effect of Land Transfer Txes on Real Estate Markets: Evidence from a Natural Experiment in Toronto. Working Paper, Univertsity of Toronto (forthcoming in Journal of Urban Economics).

DEUTSCHE INDUSTRIE- UND HANDELSKAMMER (2006). Fußball-WM 2006, Auswirkungen auf die Unternehmen. Retrieved 21 November 2006, from http://www.dihk.de/ index.html?/inhalt/themen/branchen/tourismus/fussball/wirtschaft.html.

DEUTSCHE POSTBANK AG (2005a). FIFA Fußball-Weltmeisterschaft 2006 - Deutsche Wirtschaft steht als Gewinner bereits fest. Retrieved 18 November 2006, from http://www.postbank.de/Datei/RSpezialFebruar05.pdf.

DEUTSCHE POSTBANK AG (2005b). FIFA Fußball-Weltmeisterschaft 2006 - Signifikante Arbeitsplatz- und Beschäftigungszuwächse in einzelnen Branchen. Retrieved 18 November 2006, from http://www.postbank.de/Datei/RSpezialJuli05.pdf.

DEUTSCHE POSTBANK AG (2006). FIFA Fußball-Weltmeisterschaft 2006 - Kleine und "ärmere" Austragungsorte profitieren am Meisten. Retrieved 18 November 2006, from http://postbank.de/Datei/RSpezialJanuar06.pdf.

ENDERS, W. (1995). Applied Econometric Time Series. New York: Wiley \& Sons.

FEDDERSEN, A., GRÖTZINGER, A. L., \& MAENNIG, W. (2009). Investment in Stadia and Regional Economic Development - Evidence from FIFA World Cup 2006. International Journal of Sport Finance, 4(4), 221-239.

FIFA. (2006). World Cup 2006 in Germany, Stadia [Electronic Version]. Retrieved 12th May 2006 from http://fifaworldcup.yahoo.com/06/de/d/stadium/index.html.

HAGN, F., \& MAENNIG, W. (2008). Employment Effects of the Football World Cup 1974 in Germany. Labour Economics, 15(5), 1062-1075.

HAGN, F., \& MAENNIG, W. (2009). Labour Market Effects of the 2006 Soccer World Cup in Germany. Applied Economics, 41(25), 3295-3302. 
HALVORSEN, R., \& PALMOUIST, R. (1980). The Interpretation of Dummy Variables in Semilogarithmic Equations. American Economics Review, 70(3), 474-475.

HOTCHKISS, J. L., MOORE, R. E., \& ZOBAY, S. M. (2003). Impact of the 1996 Summer Olympic Games on Employment and Wages in Georgia. Southern Economic Journal, 69(3), 691-704.

IMBENS, G. W., \& LEMIEUX, T. (2008). Regression Discontinuity Designs: A Guide to Practice. Journal of Econometrics, 142(2), 615-635.

JASMAND, S., \& MAENNIG, W. (2008). Regional Income and Employment Effects of the 1972 Munich Summer Olympic Games. Regional Studies, 42(7), 991-1002.

KAVETSOS, G., \& SZYMANSKI, S. (2009). National Well-Being and International Sports Events. Journal of Economic Psychology, DOI:10.1016/j.joep.2009.1011.1005.

KURSCHEIDT, M., PREUß, H., \& SCHÜTTE, N. (2008). Konsuminduzierter Impakt von Sportgroßevents am Beispiel der Fußball-WM 2006 - Befragungsergebnisse und Implikationen für die Euro 2008 [Consumption Induced Impact of Major Sport Events for the Case of the Football World Cup 2006: Survey Results and Implications for Euro 2008]. Wirtschaftspolitische Blätter, 55(1), 79-94.

LEEDS, M. A. (2008). Do Good Olympics Make Good Neighbors? Contemporary Economic Policy, 26(3), 460-467.

MAENNIG, W. (2007). One Year Later: A Re-Appraisal of the Economics of the 2006 Soccer World Cup. Hamburg Contemporary Economic Discussions, No. 10.

MATHESON, V. (2006). Mega-Events: The Effect of the World's Biggest Sporting Events on Local, Regional, and National Economies, Working Paper NO. 60-10. Worcester, MA: Department of Economics, College of the Holy Cross.

MATHESON, V. A. (2005). Contrary Evidence on the Economic Effect of the Super Bowl on the Victorious City. Journal of Sports Economics, 6(4), 420-428.

PORTER, P. K. (1999). Mega-Sports Events as Municipal Investments: A Critique of Impact Analysis. In J. Fizel, E. Gustafson, \& L. Hadley (Eds.), Sports Economics: Current Research (pp. 61-74). Westport, CT: Praeger Publishers.

STERKEN, E. (2006). Growth Impact of Major Sporting Events. European Sport Management Quarterly, 6(4), 375-389.

SZYMANSKI, S. (2002). The Economic Impact of the World Cup. World Economics, 3(1), 169-177.

TEIGLAND, J. (1999). Mega-Events and Impacts on Tourism; the Predictions and Realities of the Lillehammer Olympics. Impact Assessment and Project Appraisal, 17(4), 305-317.

WOOLDRIDGE, J. M. (2009). Introductory Econometrics: A Modern Approach (4th ed.). Mason, $\mathrm{OH}$ : South-Western Cengage Learning. 


\section{Hamburg Contemporary Economic Discussions}

(Download: http://www.uni-hamburg.de/economicpolicy/discussions.html)

01/2005 FEDDERSEN, A. / MAENNIG, W.: Trends in Competitive Balance: Is there Evidence for Growing Imbalance in Professional Sport Leagues?, January 2005.

02/2005 SIEVERS, T.: Information-driven Clustering - An Alternative to the Knowledge Spillover Story, February 2005.

03/2005 SIEVERS, T.: A Vector-based Approach to Modeling Knowledge in Economics, February 2005.

04/2005 BUETTNER, N. / MAENNIG, W. / MENSSEN, M.: Zur Ableitung einfacher Multiplikatoren für die Planung von Infrastrukturkosten anhand der Aufwendungen für Sportstätten - eine Untersuchung anhand der Fußball-WM 2006, May 2005.

01/2006 FEDDERSEN, A.: Economic Consequences of the UEFA Champions League for National Championships - The Case of Germany, May 2006.

02/2006 FEDDERSEN, A.: Measuring Between-season Competitive Balance with Markov Chains, July 2006.

03/2006 FEDDERSEN, A. / VÖPEL, H.: Staatliche Hilfen für Profifußballclubs in finanziellen Notlagen? - Die Kommunen im Konflikt zwischen Imageeffekten und Moral-Hazard-Problemen, September 2006.

04/2006 MAENNIG, W. / SCHWARTHOFF, F.: Stadium Architecture and Regional Economic Development: International Experience and the Plans of Durban, October 2006. 


\section{Hamburg Contemporary Economic Discussions}

(Download: http://www.uni-hamburg.de/economicpolicy/discussions.html)

01

02

03

04

05

06

07

08

09

10

11

12

13

AHLFELDT, G. / MAENNIG, W.: The Role of Architecture on Urban Revitalization: The Case of "Olympic Arenas" in Berlin-Prenzlauer Berg, 2007.

FEDDERSEN, A. / MAENNIG, W. / ZIMMERMANN, P.: How to Win the Olympic Games - The Empirics of Key Success Factors of Olympic Bids, 2007.

AHLFELDT, G. / MAENNIG, W.: The Impact of Sports Arenas on Land Values: Evidence from Berlin, 2007.

DU PLESSIS, S. / MAENNIG, W.: World Cup 2010: South African Economic Perspectives and Policy Challenges Informed by the Experience of Germany 2006, 2007.

HEYNE, M. / MAENNIG, W. / SUESSMUTH, B.: Mega-sporting Events as Experience Goods, 2007.

DUST, L. / MAENNIG, W.: Shrinking and Growing Metropolitan Areas - Asymmetric Real Estate Price Reactions? The Case of German Single-family Houses, 2007.

JASMAND, S. / MAENNIG, W.: Regional Income and Employment Effects of the 1972 Munich Olympic Summer Games, 2007.

HAGN, F. / MAENNIG W.: Labour Market Effects of the 2006 Soccer World Cup in Germany, 2007.

HAGN, F. / MAENNIG, W.: Employment Effects of the World Cup 1974 in Germany.

MAENNIG, W.: One Year Later: A Re-appraisal of the Economics of the 2006 Soccer World Cup, 2007.

AHLFELDT, G., MAENNIG, W.: Assessing External Effects of City Airports: Land Values in Berlin, 2007.

AHLFELDT, G.: If Alonso was Right: Accessibility as Determinant for Attractiveness of Urban Location, 2007.

AHLFELDT, G.: A New Central Station for a Unified City: Predicting Impact on Property Prices for Urban Railway Network Extension, 2007. 


\section{Hamburg Contemporary Economic Discussions}

(Download: http://www.uni-hamburg.de/economicpolicy/discussions.html)

FEDDERSEN, A. / MAENNIG, W.: Arenas vs. Multifunctional Stadia Which Do Spectators Prefer?, 2007.

AHLFELDT, G. / FEDDERSEN, A.: Geography of a Sports Metropolis, 2007.

FEDDERSEN, A. / GRÖTZINGER, A. / MAENNIG, W.: New Stadia and Regional Economic Development - Evidence from FIFA World Cup 2006 Stadia, 2008.

AHLFELDT, G. / MAENNIG, W.: Monumental Protection: Internal and External Price Effects, 2008.

MAENNIG, W. / PORSCHE, M.: The Feel-good Effect at Mega Sport Events - Recommendations for Public and Private Administration Informed by the Experience of the FIFA World Cup 2006, 2008.

AHLFELDT, G.: The Train has Left the Station: Real Estate Price Effects of Mainline Realignment in Berlin, 2008.

MAENNIG, W. I WELLBROCK, C.-M.: Sozio-ökonomische Schätzungen Olympischer Medaillengewinne: Analyse-, Prognose- und Benchmarkmöglichkeiten, 2008.

MAENNIG, W. / ALLERMS, S.: South Africa 2010: Economic Scope and Limits, 2008.

AHLFELDT, G. / FEDDERSEN, A.: Determinants of Spatial Weights in Spatial Wage Equations: A Sensitivity Analysis, 2008.

AHLFELDT, G. / WENDLAND, N.: Fifty Years of Urban Accessibility: The Impact of Urban Railway Network on the Land Gradient in Industrializing Berlin, 2008.

AHLFELDT, G. I FRANKE, B. / MAENNIG, W.: Terrorism and the Regional and Religious Risk Perception of Foreigners: The Case of German Tourists, 2009.

FEDDERSEN, A. / MAENNIG, W.: Wage and Employment Effects of the Olympic Games in Atlanta 1996 Reconsidered, 2009.

AHLFELDT, G. I MAENNIG, W.: Impact of Non-Smoking Ordinances on Hospitality Revenues: The Case of Germany, 2009. 


\section{Hamburg Contemporary Economic Discussions}

(Download: http://www.uni-hamburg.de/economicpolicy/discussions.html)

BJØRNSKOV , C. / DREHER, A. / FISCHER, J.A.V. / SCHNELLENBACH, J.: On the Relation Between Income Inequality and Happiness: Do Fairness Perceptions Matter?, 2009.

AHLFELDT, G. / MAENNIG, W. / OSTERHEIDER, T.: Regional and sectoral effects of a common monetary policy: evidence from Euro Referenda in Denmark and Sweden, 2009.

FEDDERSEN, A. / JACOBSEN, S. / MAENNIG, W.: Sports Heroes and Mass Sports Participation - The (Double) Paradox of the "German Tennis Boom", 2009.

AHLFELDT, G. / MAENNIG, W. / ÖLSCHLÄGER, M.: Lifestyles and Preferences for (Public) Goods: Professional Football in Munich, 2009.

FALCH, T. / FISCHER, J.A.V.: Public Sector Decentralization and School Performance: International Evidence, 2010.

AHLFELDT, G.: Blessing or curse? Appreciation, Amenities, and Resistance around the Berlin "Mediaspree", 2010.

FEDDERSEN, A. / MAENNIG, W.: Sectoral Labor Market Effects of the 2006 FIFA World Cup, 2010. 


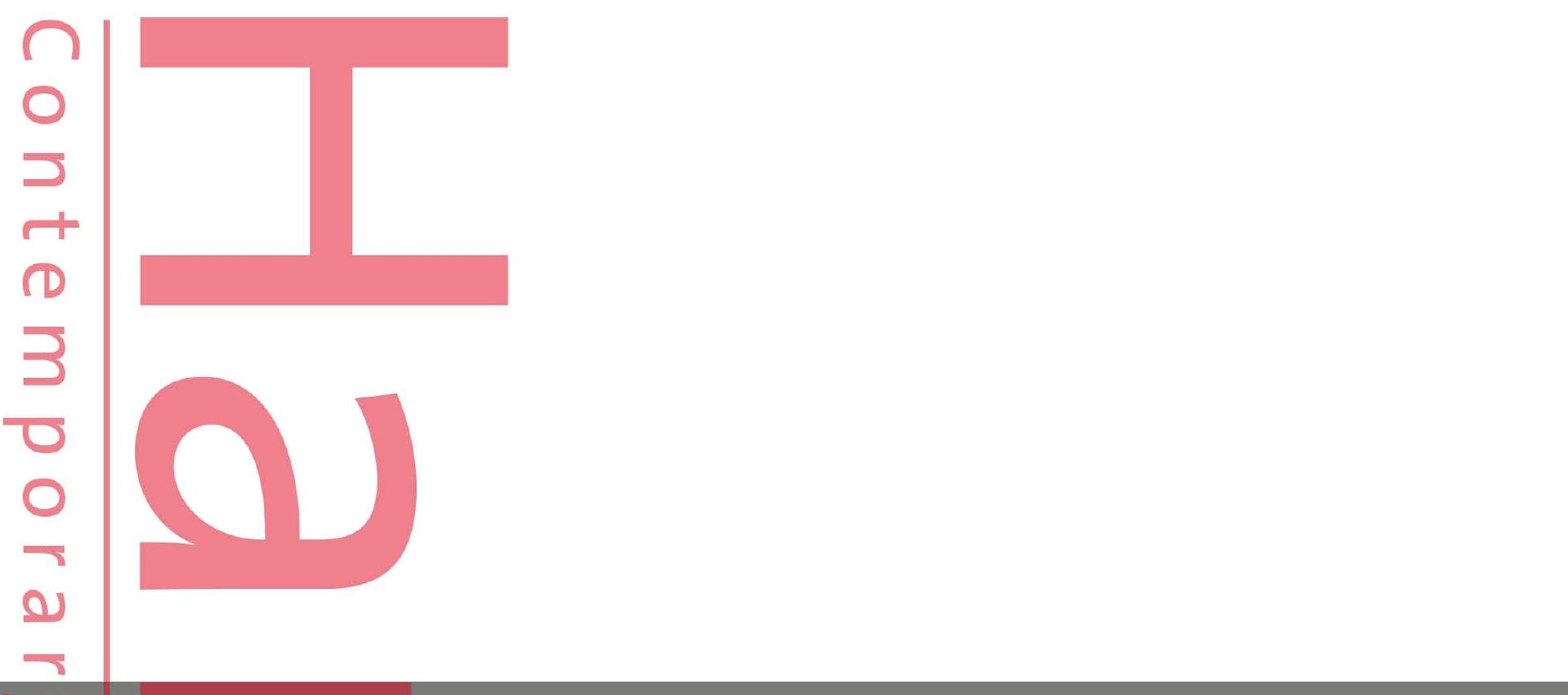

ISSN 1865-2441 (PRINT) ISSN $1865-7133$ (ONLINE)

ISBN 978-3-940369-80-2 (PRINT) ISBN 978-3-940369-81-9 (ONLINE) 